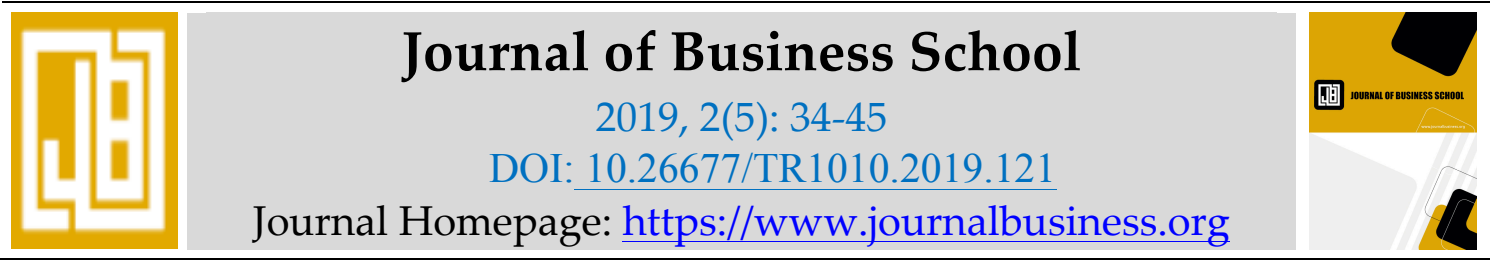

\title{
The Scientific Analysis of Some European Corporate Governance Standards After Financial Crisis - Case in Belgium and The Netherlands
}

\author{
Dinh Tran Ngoc Huy, PhD candidate, MBA \\ Binh Duong University, Binh Duong Viet Nam - Graduate School of International \\ Management, International University of Japan, Niigata, Japan. dtnhuy2010@gmail.com
}

\begin{abstract}
After the recent global crisis, corporate scandals and bankruptcy in US and Europe, there is some certain evidence on weak auditing, risk management, accounting and audit system. This paper chooses a different analytical approach and among its aims is to give some systematic opinions on corporate governance criteria as a benchmark for stock markets.

Firstly, it classifies limited Western European representative corporate governance (CG) standards into groups: The Netherlands and Belgium latest CG principles covered in group 1 while it uses OECD and ICGN principles as reference. Secondly, it, through analysis, identifies differences and advantages between above set of standards which are and have been used as reference principles for many relevant organizations.

Third, it establishes a selected comparative set of standards for a typical Western European representative corporate governance system in accordance to international standards. Last but not least, this paper covers some ideas and policy suggestions.
\end{abstract}

Keywords: Corporate Governance Standards, Board Structure, Code Of Best Practice, Financial Crisis, Corporate Scandals, Market Manipulation, Internal Audit

\section{Introduction}

After corporate scandals happening during and after global monetary and financial crises, it is necessary to re-evaluate code of corporate governance. In reality, many nations re-issue their principles of corporate governance as guidelines for their market and companies. This paper selects an easy-reading writing style, and it finds out that there is still some academic words need to be explained in further.

The organization of paper contents is organized as following. As our previous series of paper, Research literature and theories are covered in the first two sessions. Next, it followed by introduction of our research methodology in session $3\left(3^{\text {rd }}\right)$. Continuously, session four (4) covers our familiar groups of empirical findings. And our conclusion and policy suggestion is covered in the fifth $\left(5^{\text {th }}\right)$ session. Before last, there are exhibit session which covers some 
summary of this paper's analysis and comparison. And lastly, a glossary note is provided with information for reference and because of reducing repeating terminology.

\section{Body of Manuscript}

\section{Research literature review}

There are many and controversial opinions on corporate governance theories and practices. For example, Jensen and Meckling (1976) presented their conceptual agency theory on the separation of ownership and management. Belgian Code 2009 stated that corporate governance is a set of rules and behaviors which determine how companies are managed and controlled.

Besides, Thailand 2006 Code defines CG as a set of structures and processes of the relationship b.t a firm's board of directors, its MGT and its shareholders to boost the firm's competitiveness, growth and long-term shareholder value with taking into account the interests of other stakeholders. Malaysian Code on CG 2012 defines CG as the process and structure used to direct and manage the business and affairs of the company towards enhancing business prosperity and corporate accountability with the ultimate objective of realizing long-term shareholder value.

Additionally, Berger et all (2013) found out that during the financial crisis, bank defaults are strongly influenced by a bank's ownership structure.

Generally, CG refers to the set of systems, processes and structures in which the company is governed.

Because there are not many researches and surveys done in Western European region on CG, next, what is the limited comparative standardized set of so-called comparative Western European corporate governance standards?

\section{Theory of Corporate Governance, Scandal and Market Manipulation}

\section{Theory of manipulation}

Market manipulation covers errors in interfering the market operation and creates false information on price or market for a financial commodity such as stock.

Aggarwal and $\mathrm{Wu}$ (2003) suggested a strong role for government regulation to discourage manipulation while encouraging greater competition for information. And more illiquid stocks are more likely to be manipulated and manipulation increases stock volatility. Imisiker and Tas (2011) presented from Istanbul stock exchange, small firms, firms with less free float rate and a higher leverage ratio are more prone to stock price manipulation.

\section{Theory of corporate governance and financial crisis}

In 2008, OECD also stated that the financial crisis revealed severe shortcomings in corporate governance.

Winter (2011) pointed that after the governance crisis 2001-2003 and the regulatory response through the Sarbanes Oxley Act and the European CG codes, the financial crisis has revealed persistent governance problems in financial institutions relating to executives, non executives and shareholders. Also, Ezzine and Olivero (2013) found out that effective governance mechanisms enhance the ability of firms to absorb a stock market crisis. Guota et all (2013) pointed that there is the lack of significant impact of corporate governance quality on performance. And well governed firms do not outperform poorly governed firms.

Hence, we can see, there exist various views on corporate governance and its importance. 


\section{Research methodology}

Firstly, we analyze and compare corporate governance principles in each groups including: 1) Group 1 - Limited Western European CG representative standards including Belgian Code 2009 and The Netherlands Corporate Governance Principles;

Secondly, We also use, but not limited to, international standards of corporate governance such as: ICGN and OECD Corporate Governance Principles and Enhancing Banking CG Code 1999 which have many modifications in corporate governance principles after the crisis period.

Then, we propose what so-called limited comparative Western European corporate governance principles which are aiming to create a basic background for relevant corporations interesting in different aspects of corporate governance subjects and functions as the recommendation to relevant countries' government and other relevant organizations for public policy and necessary evaluation.

Last but not least, for a summary of our standards, see Exhibit and the below table 1 and 2 in relevant sessions.

\section{Empirical findings}

A- Findings on Corporate governance issues after financial crisis, corporate scandals and market manipulation

Some certain popular issues including: the roles and duties of CEO and senior management.

Also, we can find out another corporate governance (CG) issue. It is, the lack of descriptions of an effective risk management system.

\section{B- Findings on Ways of Manipulation during Corporate Scandals}

Several Manipulation Techniques found out during corporate scandals involve, but not limited to:

\section{B.1 - The manipulation techniques in the income statement:}

In Waste Management Scandal (1998), a Houston publicly traded waste management firm, there is a report of $\$ 1.7 \mathrm{~b}$ in fake income.

\section{B.2 - The manipulation techniques in both the income statement and balance sheet:}

In the case of Refco financial service company, based in New York, entered the crisis and Chapter 11 in 2005 when its CEO had concealed $\$ 430 \mathrm{~b}$ in bad debts.

\section{B.3 - The manipulation techniques relevant to international accounting practice code:}

In the scandal case of Global Crossing Ltd., a telecommunication firm, there is a failure in using international accounting standards (GAAP) in making financial reports. The company did not fairly present financial statements.

\section{B.4 - Other manipulation techniques net belong to above classifications:}

In some scandals, there is management manipulation which causes the loss of investments. In the case of Worldcom, a telecomm scandal, directors have used false accounting methods to manipulate stock prices after falling.

\section{C- Actions on Preventing or Controlling negative manipulation}


Among necessary actions to control negative market manipulation are, but not limited to, the mechanism of the board and its committees aiming to increase effectiveness and transparency with investors. Accounting and financial reporting process are also taken into account.

\section{D- Findings on Construction of Comparative Western European Corporate Governance Standards}

These findings will be shown in a detailed analysis of a model indicated in the later sessions.

$<$ D.1>- Limited Western European Corporate Governance standards analysis

\section{The Belgium Code of Corporate Governance 2009}

The Belgian Code 2009 has been modified from its first version in 2004.

Among its advantages are, but not limited to, CG charter and CG statement. CG statement of the annual report covers a description of operation of committees, whereas CG charter includes direct or indirect relationship of the firm and major shareholders.

Generally speaking, The Code focuses on Board, Committees and disclosure of remuneration policy of executive managers mentioned in the CG statement. (see Exhibit 1 ).

\section{The Netherlands Corporate Governance Principles}

The Netherlands Best practices 2006 cover some major CG matters such as board roles and risk management.

Different from other European Codes, one of its distinctions is clarifying roles of supervisory board (SB). For example, SB should meet regularly and retain effective control over the firm.

For more information, please see Exhibit 2. However, it would be better to mention guidelines of CEO roles.

\section{Comparison between the Belgian and the Netherlands Corporate Governance Principles}

A lot of information on roles of Board is in the Belgian Code 2009. For example, it pointed Board ensures the integrity and timely disclosure of the firm F.S. But it would be better to give guidelines for a compliance officer. (see Exhibit 1).

On the other hand, the Netherlands Code stated roles of SB in ensuring appropriate plans and policies for the firm. Besides, it also oversees business performance.

Table 1 - A so-called Limited Western European CG representative standards

\begin{tabular}{|c|c|c|}
\hline Subjects or parties & Main quality factors & Sub quality factors \\
\hline Audit committee & $\begin{array}{l}\text { AC discuss significant financial } \\
\text { reporting issues with EA and } \\
\text { executive MGT; meet at least } 4 \\
\text { times a year; twice a year meet IA } \\
\text { and EA to discuss weakness of IC; }\end{array}$ & \begin{tabular}{ll}
\multicolumn{1}{c}{ New AC } & members \\
provided with & IC, RM, \\
operational, & financial, \\
accounting and & auditing \\
information; &
\end{tabular} \\
\hline CEO and The Chair & $\begin{array}{l}\text { Consider positive and negative } \\
\text { aspects if board considered the } \\
\text { former CEO as chairman; }\end{array}$ & $\begin{array}{l}\text { Chairman consults with } \\
\text { CEO setting board meeting } \\
\text { agenda; }\end{array}$ \\
\hline Corporate Secretary & $\begin{array}{l}\text { Ensure good information flow } \\
\text { within board, committee, executive } \\
\text { MGT and NEDs; }\end{array}$ & $\begin{array}{l}\text { Advise board on all } \\
\text { governance matters; } \\
\text { regularly report to board; }\end{array}$ \\
\hline Compliance officer & $\begin{array}{c}\text { A compliance committee } \\
\text { installed, or a high level compliance }\end{array}$ & Can be company lawyer; \\
\hline
\end{tabular}




\begin{tabular}{|c|c|c|}
\hline & U, & \\
\hline Board of Directors & $\begin{array}{l}\text { No individual or group } \\
\text { dominate board's decision making; } \\
\text { organizing meetings using internet, } \\
\text { video or telephone; }\end{array}$ & $\begin{array}{l}\text { Ensure accuracy and } \\
\text { completeness of CG charter } \\
\text { and CG statement; }\end{array}$ \\
\hline Independent director & $\begin{array}{l}\text { Independency of judgement and } \\
\text { objectivity in making board } \\
\text { decisions; }\end{array}$ & $\begin{array}{l}\text { Not an executive member } \\
\text { of board; }\end{array}$ \\
\hline $\begin{array}{l}\text { Supervisory board to } \\
\text { the Management }\end{array}$ & $\begin{array}{l}\text { SB ensures individuals involved } \\
\text { in daily MGT are of professional, } \\
\text { integrity and social and moral; }\end{array}$ & $\begin{array}{l}\text { SB ensures MGT take } \\
\text { follow-up actions on } \\
\text { supervisory } \\
\text { recommendations; }\end{array}$ \\
\hline Supervisory to the & Meet regularly and retain & Committee of \\
\hline Board of Directors & effective control over the firm & $\begin{array}{l}\text { comprises a majority of } \\
\text { unrelated supervisory } \\
\text { directors; the engagement } \\
\text { of an outside adviser; }\end{array}$ \\
\hline Internal control & $\begin{array}{l}\text { A framework of IC set by } \\
\text { executive MGT approved by board; }\end{array}$ & $\begin{array}{l}\text { Main risks identified and } \\
\text { managed; }\end{array}$ \\
\hline Internal audit & AC review IA work program; & $\begin{array}{l}\text { AC recommends } \\
\text { appointment/removal head } \\
\text { of IA }\end{array}$ \\
\hline External audit & $\begin{array}{l}\text { Examine with AC safety } \\
\text { measures taken to decrease risks; }\end{array}$ & $\begin{array}{l}\text { Comment on the true } \\
\text { and fair view of the firm } \\
\text { assets and liabilities, } \\
\text { financial positions; report } \\
\text { AC key matters of FS; }\end{array}$ \\
\hline $\begin{array}{l}\text { Disclosure } \\
\text { transparency }\end{array}$ & $\begin{array}{l}\text { SB ensures timely and accurate } \\
\text { disclosure; }\end{array}$ & $\begin{array}{l}\text { Executive MGT prepare } \\
\text { firm disclosure of F.S; }\end{array}$ \\
\hline Shareholders & $\begin{array}{l}\text { Controlling shareholders can } \\
\text { appoint representatives to the } \\
\text { board; Board ensures its obligations } \\
\text { to shareholders are met; }\end{array}$ & $\begin{array}{l}\text { Controlling shareholders } \\
\text { can appoint representatives } \\
\text { to the board; }\end{array}$ \\
\hline $\begin{array}{l}\text { The corporation as a } \\
\text { whole entity }\end{array}$ & $\begin{array}{l}\text { Has CG code with provisions and } \\
\text { guidelines on how the firm } \\
\text { implements the provisions of the } \\
\text { code; }\end{array}$ & $\begin{array}{l}\text { CG charter on firm website } \\
\text { and CG statement on } \\
\text { annual report; }\end{array}$ \\
\hline
\end{tabular}

\section{Conclusion}

To overcome weaknesses from CG during crises, The Belgian Code 2009 suggested Board roles are important and skills, experience and knowledge of new board candidate should be evaluated (see Exhibit 1).

Besides, the Netherlands Code included guidelines for supervisory board (SB) including an orientation and education program for new members of SB.

In consideration of corporate governance issues analyzed in the previous sessions, we proposed the main and sub quality factors in this paper a set of general comparative Western European corporate governance standards in a limited model with selected countries. Though limited, it has some implications for further research and proper recommendations to relevant 
government and organizations. And it also provides relevant academic and non-academic, lawyer and consultant, board and non-board people with minimum information for further researches.

\section{REFERENCES}

Allen, F., and Gale, D., (1992), Stock Price Manipulation, Review of Financial Studies

Bellouma, Meryem., (2012), Governance Mechanisms and Buyer Supplier Relationship in Tunisian Exporting SMEs, International Journal of Corporate Governance

Campa, Domenico., and Donnelly, Ray., (2013), Board Structure and Monitoring Effects in Different Institutional Settings: A Comparison between Italy and the UK, International Journal of Corporate Governance

Dallas, Lynne., (2011), Short-Termism, The Financial Crisis and Corporate Governance, Journal of Corporation Law

Essen, Marc., Engelen, Peter., and Carney, Michael., (2013), Does “Good" Corporate Governance Help in A Crisis? The Impact of Country and Firm Level Governance Mechanisms in the European Financial Crisis, Corporate Governance: An International Review

IFRs and US GAPP, Deloitte, 2007.

Khwaja, Asim Ijaz., Mian, Atif., (2005), Unchecked intermediaries:Price manipulation in an emerging stock market, Journal of Financial Economics 78 (2005) 243-241

Niu, Flora., (20008), Director Cash Compensation, Ownership Structure and Director Pay for Performance, International Journal of Corporate Governance

OECD Corporate Governance Guidelines, OECD, 1999

www.iasplus.com

www.cbc.to

www.cii.org/corp_govenance.asp 
Exhibit

Exhibit 1 - The 2009 Belgian Code of Corporate Governance (a short summary evaluation)

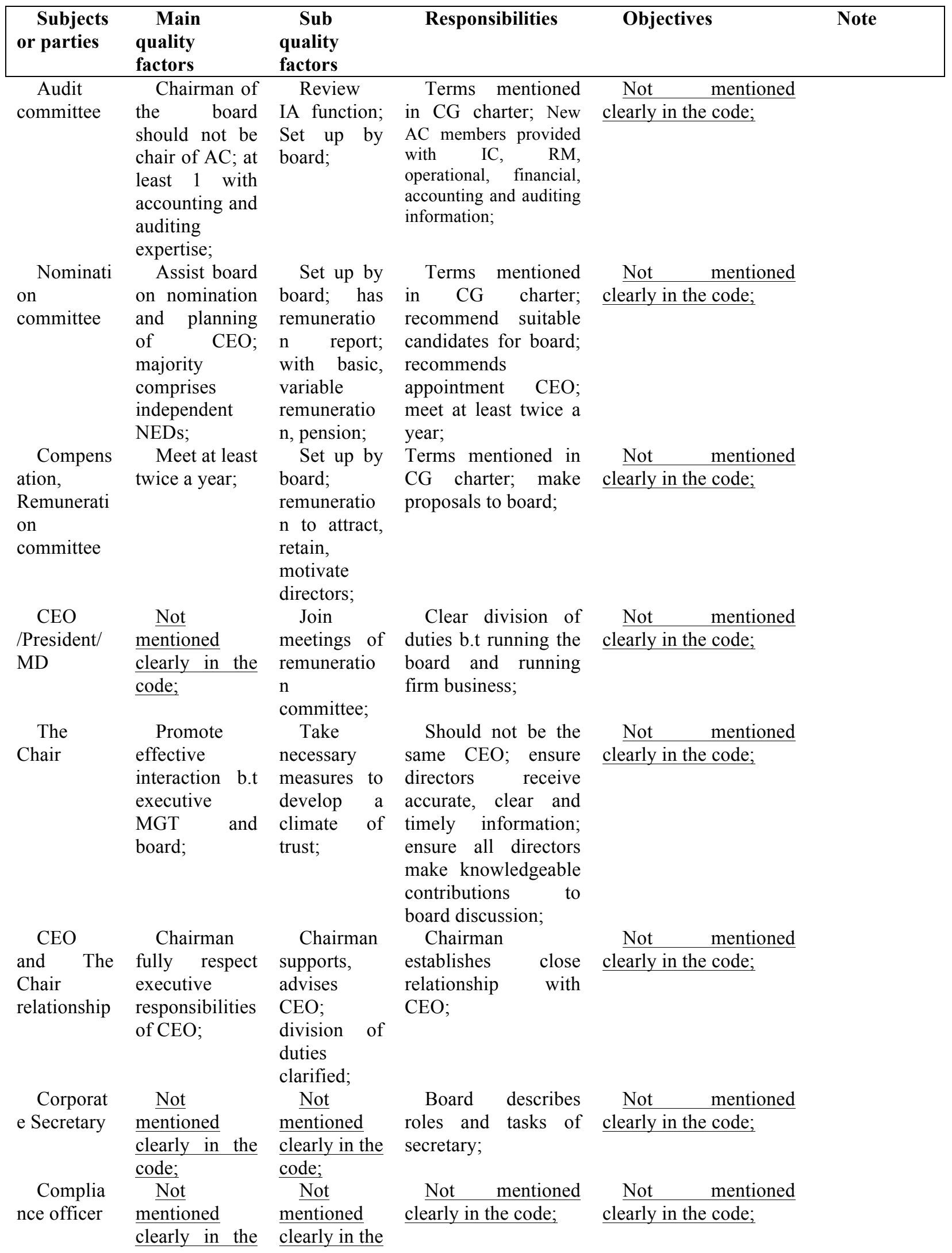




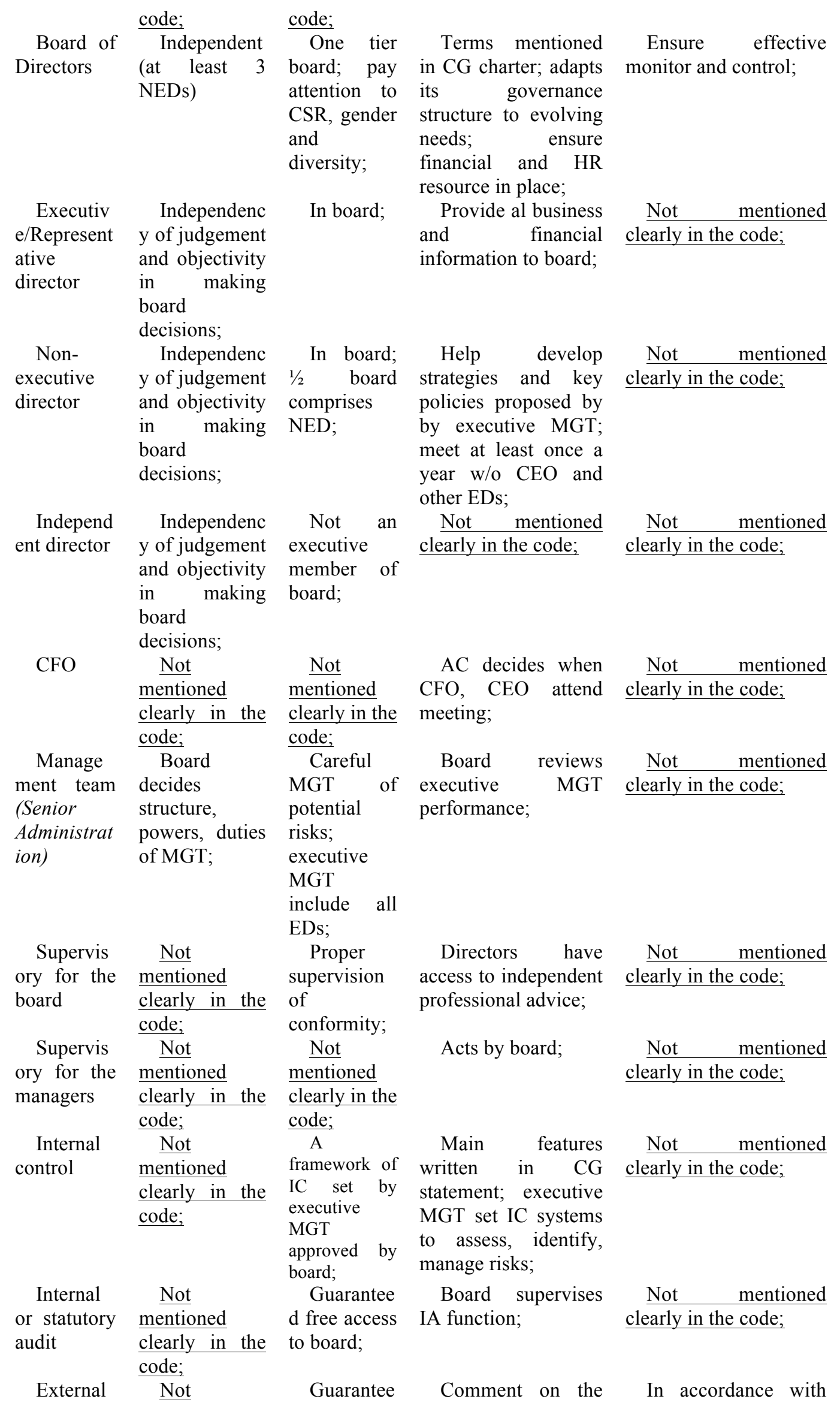




\begin{tabular}{|c|c|}
\hline udit & $\begin{array}{l}\text { mentioned } \\
\text { clearly in the } \\
\text { code; }\end{array}$ \\
\hline 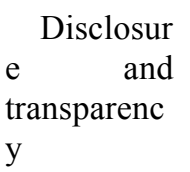 & $\begin{array}{l}\text { Executive } \\
\text { MGT prepare } \\
\text { firm disclosure } \\
\text { of F.S; }\end{array}$ \\
\hline \begin{tabular}{l}
\multicolumn{2}{c}{ Sharehol } \\
ders and \\
Minority \\
Stockholder
\end{tabular} & $\begin{array}{l}\text { A website } \\
\text { section } \\
\text { describes their } \\
\text { rights to join } \\
\text { GM; }\end{array}$ \\
\hline $\begin{array}{l}\text { Accounta } \\
\text { bility }\end{array}$ & $\frac{\frac{\text { Not }}{\text { mentioned }}}{\text { clearly in the }}$ \\
\hline ip Leadersh & $\begin{array}{l}\frac{\text { Not }}{\text { mentioned }} \\
\text { clearly in the } \\
\text { code; }\end{array}$ \\
\hline
\end{tabular}

$\mathrm{e}^{\text {Employe }} \frac{\text { Not }}{\frac{\text { mentioned }}{\text { clearly in the }}}$

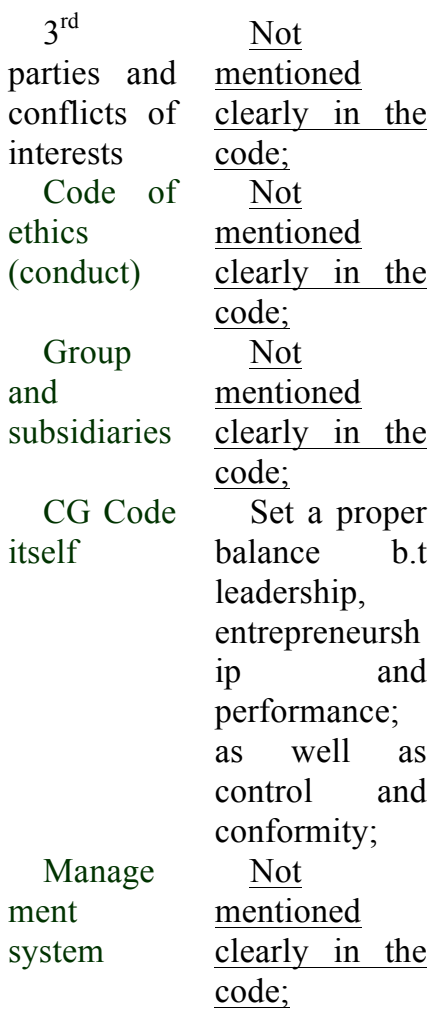

$d$ free access true and fair view of to board; the firm assets and liabilities, financial positions; report AC key matters of FS;

Through Allow effective $\mathrm{CG}$ charter external monitoring; and $\mathrm{CG}$ statement;

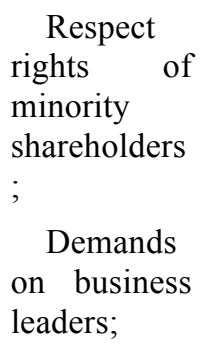

\section{Demands}

on business leaders;

Chairman responsible for leadership of board;

$\mathrm{AC}$ decides whether senior employee join meeting;

Have policy;

Not mentioned clearly in the code;

$$
\text { Not }
$$
mentioned clearly in the code;

Ensure leadership, integrity and transparency in the

decision

making process;

\section{Not} mentioned clearly in the code;

\section{Controlling}

of shareholders can appoint representatives to the board; Board ensures its obligations to shareholders are met;

Executive MGT accountable to board for the discharge of its duties;

$$
\text { Board provides }
$$
entrepreneur leadership;

At GM, directors answer questions which do not prejudice firm, employee, shareholders;

Each board member avoid direct and indirect conflicts of interest;

Not mentioned clearly in the code;

A policy for transactions with related firms included in $\mathrm{CG}$ charter;

Help determines firm goals; one-tier board model; has principles, provisions and guidelines;

Main features of mentioned in $\mathrm{CG}$ statement; financial reporting framework in Belgium;

A high level of transparency; promote effective dialogue with (potential)

shareholders;

Not mentioned clearly in the code;

Not mentioned clearly in the code;

Not mentioned clearly in the code;

Not mentioned clearly in the code;

\section{Not mentioned clearly in the code;}

Not mentioned clearly in the code; Not mentioned risk MGT system clearly in the code;

Note $\quad$ The underlined part is describing some more works needed to be done for relevant subjects and parties. 
Exhibit 2 - The Netherlands Code of Governance (a short summary evaluation)

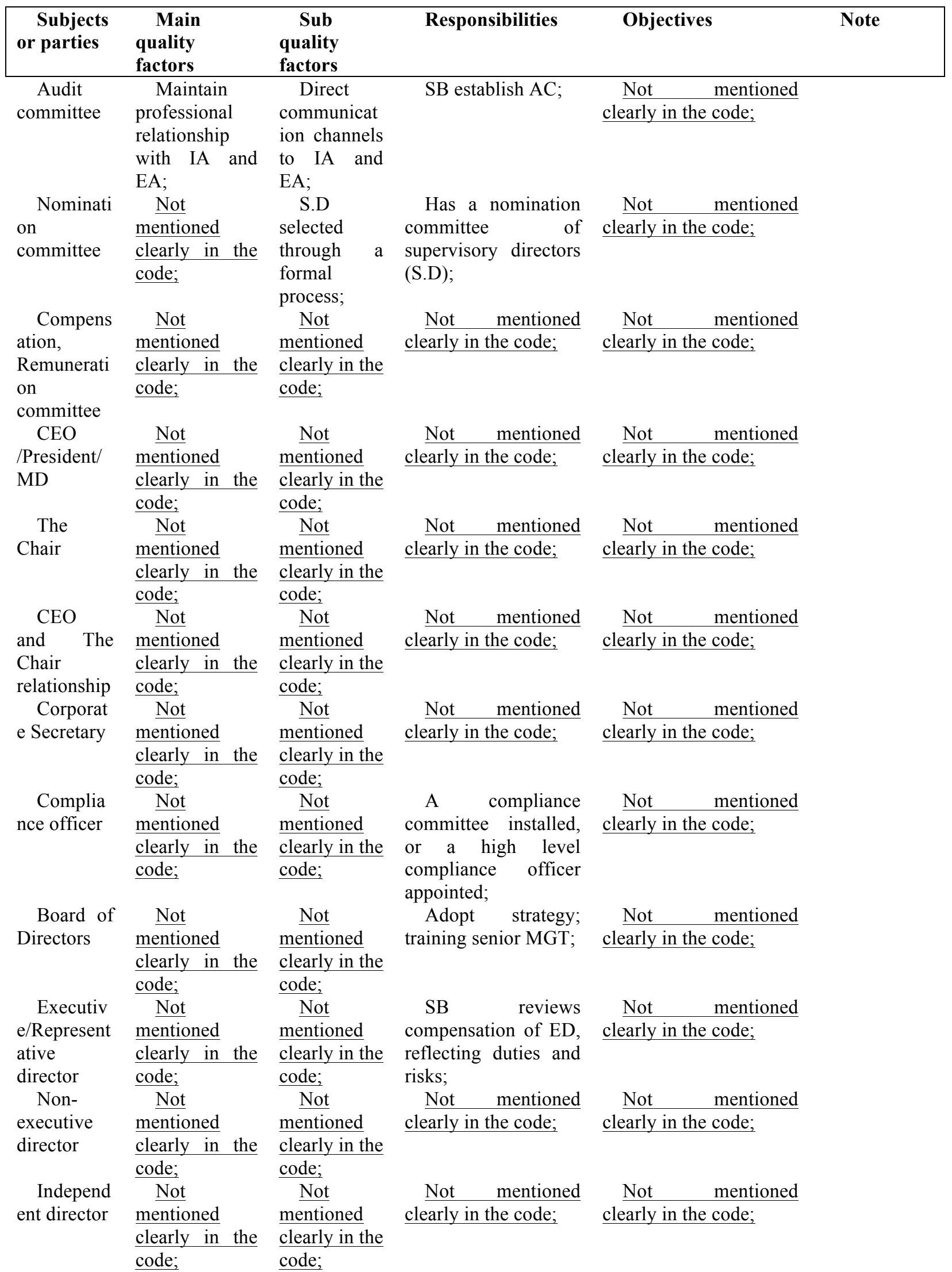




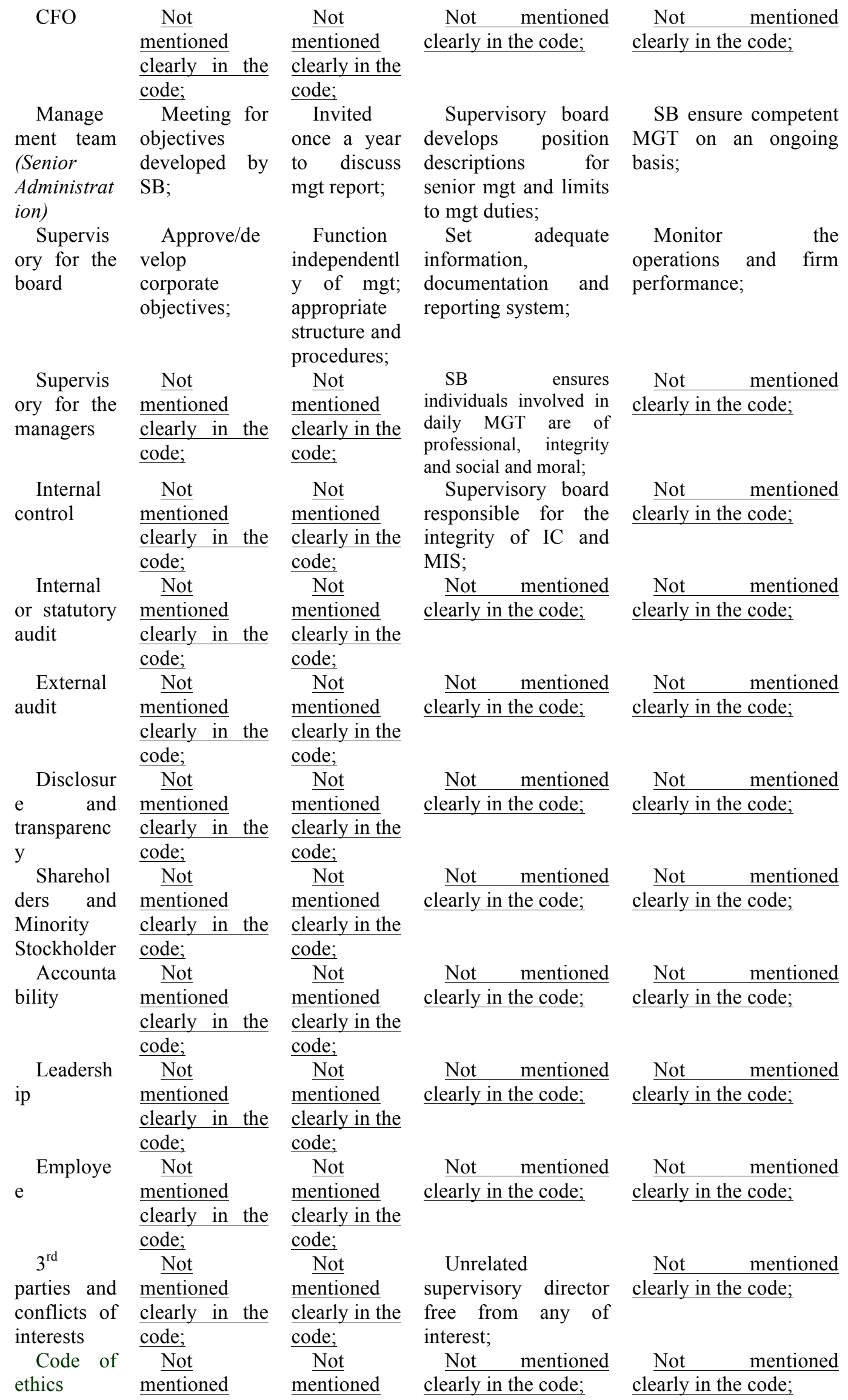


Journal of Business School, vol.2, issue.5, pp.34-45

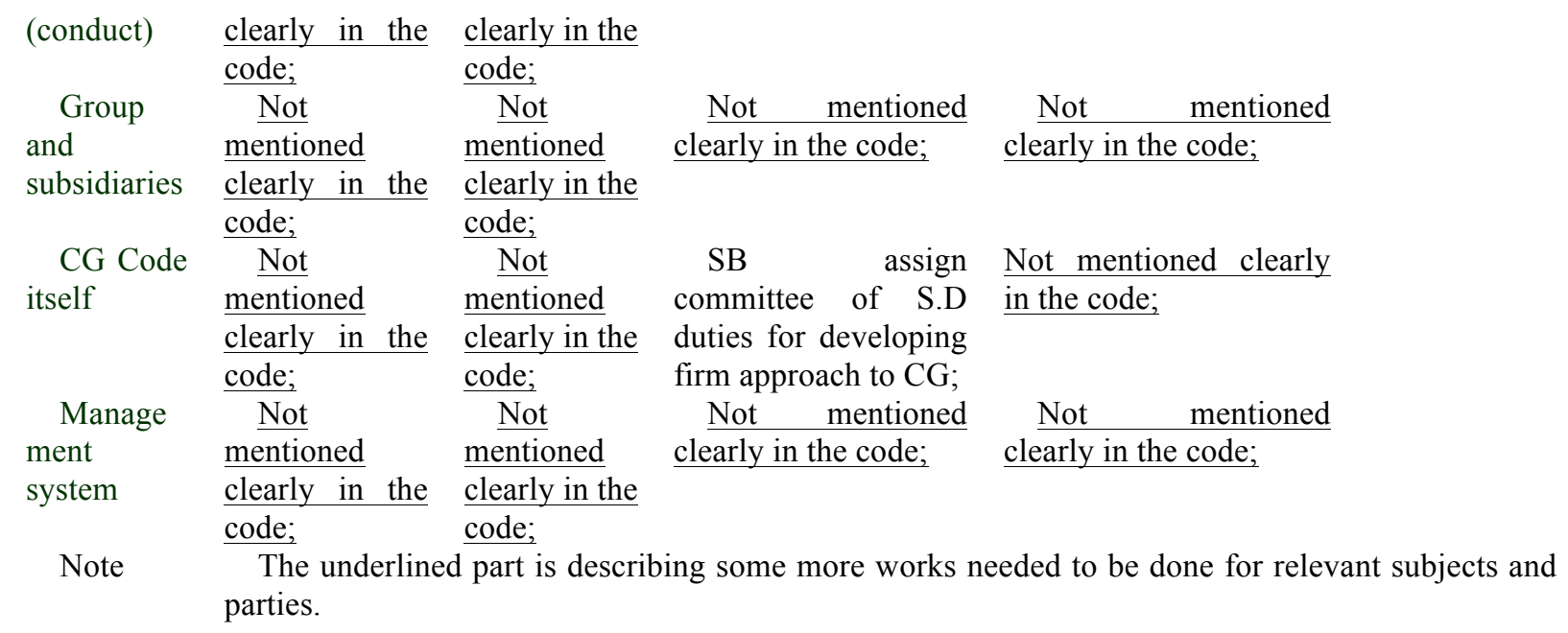

